\title{
Synthesis and Antimicrobial Activity of Furochromone, Benzofuran and Furocoumarin Derivatives Bearing Sulfonyl Moiety
}

\author{
Sadia A. Hessein, ${ }^{1}$ Marwa A. M. Sh. El-Sharief, ${ }^{2,3}$ Samir Y. Abbas, ${ }^{4, *}$ Hamdy Kh. Thabet, ${ }^{5}$ Yousry A. Ammar ${ }^{5, *}$
}

\footnotetext{
${ }_{1}$ Chemistry Department, Faculty of Science, Al-Azhar University (Girls), Nasr City, Cairo, Egypt

2 Applied Organic Chemistry Department, National Research Centre, Cairo, Egypt

3 Faculty of Science and Arts, Mohail Asser, King Khalid University, Saudi Arabia

${ }^{4}$ Organometallic and Organometalloid Chemistry Department, National Research Centre, Cairo, Egypt

5 Chemistry Department, Faculty of Science, Al-Azhar University, Nasr City, Cairo, Egypt

*Corresponding authors' e-mail addresses: samiryoussef98@yahoo.com; yossry@yahoo.com
}

RECEIVED: January 2, 2016 * REVISED: March 8, 2016 * ACCEPTED: March 14, 2016

\begin{abstract}
New visnagin-9-sulfonamide derivatives 3 and $4 a-c$ were synthesized through the reaction of visnagin-9-sulfonyl chloride 2 with amino compounds. Acetylation of compounds $4 \mathrm{~b}$ and $4 \mathrm{c}$ gave the monoacetyl and diacetyl derivatives 5 and 6 , respectively. Diazotization reaction of compound $4 \mathrm{~b}$ afforded the corresponding benzotriazole derivative 8 . Pyrazole and thiopyrimidine derivatives 9 and 10 were obtained via the opening of pyrone ring upon reaction of compound 3 with hydrazine hydrate and thiourea, respectively. In addition, hydrolysis of compound 3 with potassium hydroxide furnished the visnaginone derivative 11 which used as starting material for synthesize benzofuran derivatives 12-14 and bergaptene derivatives $15-17$. The synthesized compounds were tested for antimicrobial activity. Furochromone derivatives $3,4 a-c, 5,6$ and $\mathbf{8}$ (visnagin-9-sulfonamide derivatives) demonstrate moderate antibacterial and antifungal activities compared with the antibacterial and antifungal activites of the standard drugs. Benzofuran derivatives 11-14 (visnaginone derivatives) showed the lowest antimicrobial activity among all the compounds investigated in this study. Furocoumarin derivatives 15a,b, 16 and 17 (furobenzopyransulfonamide [bergaptensulfonamides]) are moderately active against all the tested strains.
\end{abstract}

Keywords: visnagine (furochromones), visnaginone (benzofurans), bergaptene (furocoumarins), sulfonamides, antimicrobial activity.

\section{INTRODUCTION}

D UE to the development of the bacterial resistant to many currently available antibiotic treatments, there is increasing interest in the discovery of new antimicrobial agents. ${ }^{[1-3]}$ Visnagin (4-methoxy-7-methyl-5H-furo[3,2$g$ ] chromen-5-one) is one of the essential chemical constituents of the fruits and seeds of Ammi visnaga, family Umbelliferae and it is known to possess antispasmodic properties to the ureter and bile duct, treats angina, whooping cough, gall bladder and renal colic. ${ }^{[4]}$ It is considered as a potent coronary vasodilator as well as its role in treating bronchial asthma. ${ }^{[5,6]}$ Molecules with the chromone scaffold possess wide range of biological activities, including antioxidant, antifungal, antimicrobial, antiallergenic, anti-inflammatory, antiproliferative and antitumor activities. ${ }^{[7-10]}$ Chromones represent an attractive source of medicinally interesting compounds due to their low toxicity. Many benzofurans are based on the chromone structure and they have been found to possess several therapeutically interesting biological activities. ${ }^{[11]}$ Sulfonamides are bacteriostatic antimicrobial agents and they are most effective in early stages of acute infections when organisms multiply rapidly. Sulfonamide-based compounds were extensively used for antibacterial agents and they are the second antimicrobial agents. ${ }^{[12-14]}$ These derivatives are still widely used today for the treatment of various bacterial, protozoal and fungal infections ${ }^{[15]}$ and are the first effective chemotherapeutic agent used in safe therapeutic dosage ranges. ${ }^{[16]}$ Based on the above mentioned observations and 


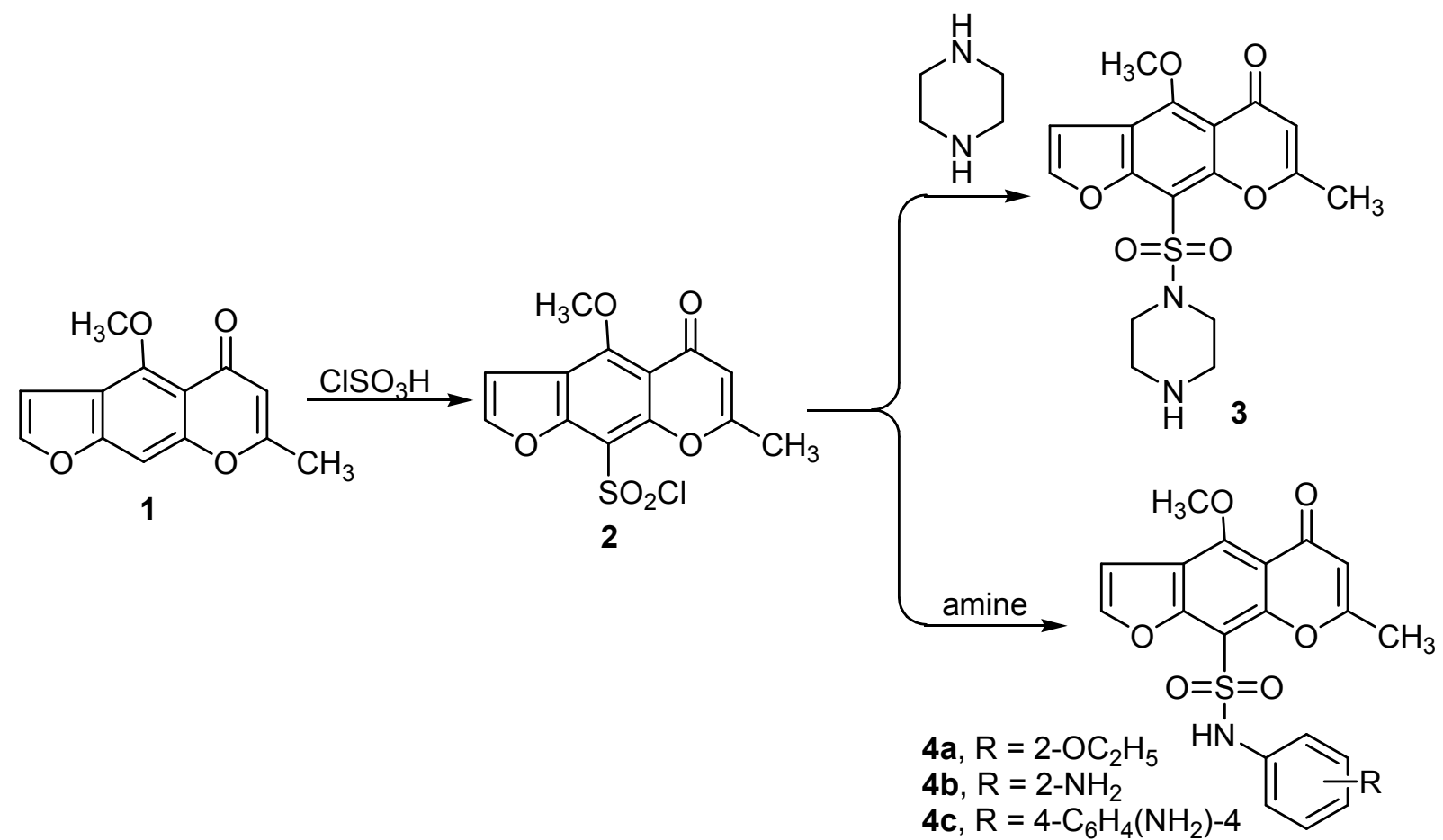

Scheme 1. Synthesis of visnagin-9-sulfonamide derivatives 3 and $4 a-c$ (Furochromone derivatives).

in continuation of our research program on the field of sulfonamide derivatives, ${ }^{[17-21]}$ antimicrobial and antifungal agents, ${ }^{[22-25]}$ we would like to report the synthesis of furochromone, benzofuran and furocoumarin derivatives containing sulfonamide moiety as a trial to obtain novel class of antibacterial and antifungal agents.

\section{RESULTS AND DISCUSSION}

\section{Chemistry}

The starting material, visnagine-9-sulfonyl chloride $\mathbf{2}^{[26]}$ was prepared from the reaction of visnagine 1 with chlorosulfonic acid. The reactivity of sulfonylchloride derivative $\mathbf{2}$ towards nitrogenous compounds was discussed. Thus, interaction of $\mathbf{2}$ with piperazine as secondary amine and o-phenatidine, o-phenylenediamine and 4,4'-diaminobiphenyl gave the corresponding sulfonamide derivatives $\mathbf{3}$ and $\mathbf{4 a - c}$, respectively (Scheme 1 ). The structures of $\mathbf{3}$ and 4 have been assigned as a reaction product on the basis of analytical and spectral data. IR spectrum of 4 a as an example displayed absorption bands at 3239 and $1661 \mathrm{~cm}^{-1}$ due to $\mathrm{NH}$ and $\mathrm{C}=\mathrm{O}$ functional groups, respectively. ${ }^{1} \mathrm{H} \mathrm{NMR}$ spectrum exhibited two sharp singlet signals at $2.40 \mathrm{ppm}$ and 3.89 ppm assignable to $\mathrm{CH}_{3}$ and $\mathrm{OCH}_{3}$ protons, another triplet and quartet signals at 1.21 and $4.22 \mathrm{ppm}$ specific for ethoxy protons. Other singlets were observed at $6.07 \mathrm{ppm}$ corresponding for chromone-H proton, multiplet signals in 6.69-7.95 ppm region owing to aromatic protons, two doublets for furan protons as well as a broad signal at $8.61 \mathrm{ppm}$ due to $\mathrm{NH}$ proton. Mass spectrum showed a molecular ion peak at $m / z=429$, corresponding to a molecular formula $\mathrm{C}_{21} \mathrm{H}_{19} \mathrm{NO}_{7} \mathrm{~S}$.

Compounds $\mathbf{4} \mathbf{b}$ and $\mathbf{4} \mathbf{c}$ are considered as key intermediates for the synthesis of some sulfonamide derivatives. Thus, treatment of $\mathbf{4} \mathbf{b}$ and $\mathbf{4} \mathbf{c}$ with acetic anhydride produced the corresponding acetyl and diacetyl derivatives 5 and 6, respectively (Scheme 2). Spectral data of the isolated product was in complete agreement with the expected structures. IR spectrum of compound 6 showed absorption bands at 3121, 1710 and $1662 \mathrm{~cm}^{-1}$ corresponding to $\mathrm{NH}$ and $2 \mathrm{C}=\mathrm{O}$ functional groups, respectively. ${ }^{1} \mathrm{H}$ NMR spectrum showed five singlet signals at 1.99, 2.32, 4.06 and 6.19 ppm characteristic for $3 \mathrm{CH}_{3}, \mathrm{OCH}_{3}$ and chromone-H protons, respectively. In addition, treatment of $\mathbf{4 b}$ with nitrous acid produced benzotriazole derivative 8 through the formation of diazonium chloride salt $\mathbf{7}$ followed by intramolecular cyclization via $\mathrm{HCl}$ elimination (Scheme 2). The structure of $\mathbf{8}$ was confirmed by elemental analysis and spectral data. IR spectrum exhibited band at $1668 \mathrm{~cm}^{-1}$ corresponding for $\mathrm{C}=\mathrm{O}$ group.

The reactivity of sulfonamide derivative $\mathbf{3}$ against binucleophilic reagents was investigated. Thus, treatment of 3 with hydrazine hydrate in ethanol under reflux afforded 


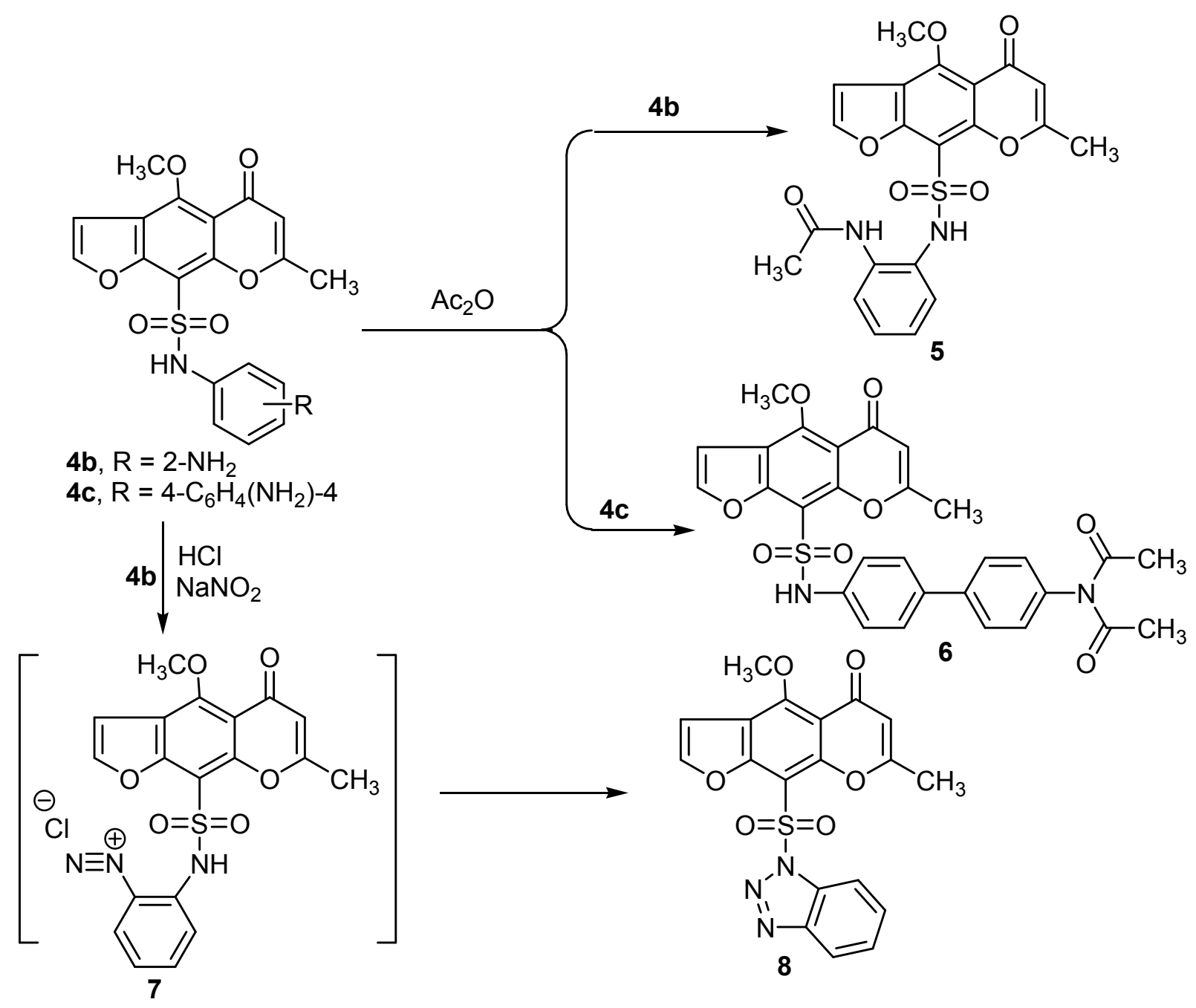

Scheme 2. Syntheses of monoacetyl and diacetyl derivatives 5 and 6 , and benzotriazole derivative 8 .

in good yield a product that was identified as pyrazole derivative $\mathbf{9}$. Formation of compound $\mathbf{9}$ is assumed to take place via nucleophilic attack of hydrazine which caused ring opening of $\gamma$-pyrone which readily undergo interamolecular cyclization by water elimination (Scheme 3). IR spectrum showed lack the band corresponding for carbonyl functional group and showed broad band around $3392 \mathrm{~cm}^{-1}$ due to $\mathrm{OH}$ and $\mathrm{NH}$ functional groups. ${ }^{1} \mathrm{H}$ NMR spectrum revealed a singlet signal at $6.45 \mathrm{ppm}$ characteristic for pyrazole proton also, another broad singlet signals at 10.41 , $11.14 \mathrm{ppm}$ due to $\mathrm{NH}$ and $\mathrm{OH}$ protons. Similarly, interaction of $\mathbf{3}$ with thiourea in ethanol containing anhydrous potassium carbonate led to ring opening. The thiopyrimidine derivative $\mathbf{1 0}$ was assigned for the reaction product on the basis of its elemental analysis and spectral data obtained. IR spectrum lacked an absorption band due to a carbonyl functional group and revealed absorption bands at: 3443 and $3221 \mathrm{~cm}^{-1}$ characteristic for $\mathrm{OH}$ and $\mathrm{NH}$ functional groups, respectively. ${ }^{1} \mathrm{H}$ NMR spectrum displayed signals at 7.34, 9.59 and 13.05 ppm assignable to pyrimidine- $\mathrm{H}, \mathrm{NH}$ and $\mathrm{OH}$ protons, respectively.

It is interesting in this connection that the hydrolysis of sulfonamide derivative 3 with potassium hydroxide caused opening $\gamma$-pyrone ring and the product of this reaction was identified on the basis of its spectral data as visnaginone derivative 11. IR spectrum revealed the presence of $\mathrm{OH}$ and $\mathrm{NH}$ stretching bands at: 3165 and $3124 \mathrm{~cm}^{-1}$ and $\mathrm{C}=\mathrm{O}$ band at: $1666 \mathrm{~cm}^{-1}$. Also, its ${ }^{1} \mathrm{H}$ NMR spectrum supported its structure, as it revealed the piperazine ring protons at 2.68-3.33 and two broad signals at 10.26 and 13.13 ppm assignable to $\mathrm{NH}$ and $\mathrm{OH}$ protons, respectively. Treatment of 11 with dimethylformamide-dimethylacetal (DMF-DMA) in toluene under reflux afforded the corresponding enaminone derivative 12. IR spectrum displayed broad absorption 
<smiles>COc1c(-c2cc(C)[nH]c(=S)n2)c(O)c2c(S(=O)(=O)N3CCNCC3)c(O)c(S(=O)(=O)N3CCNCC3)c(O)c2c1O</smiles>

Scheme 3. Syntheses of pyrazole derivative 9 and thiopyrimidine derivative 10 .<smiles>COc1c(C(C)=O)c(O)c(S(=O)(=O)N2CCNCC2)c2occc12</smiles><smiles>COc1c(C(=O)/C=C/N(C)C)c(O)c(S(=O)(=O)N2CCNCC2)c2occc12</smiles><smiles>COc1c(C(=O)/C=C/c2ccc(Cl)c(P(N)N)c2)c(O)c(S(=O)(=O)N2CCNCC2)c2occc12</smiles><smiles>COc1c(C2=NN(c3ccccc3)C(c3ccc(Cl)cc3)C2)c(O)c(S(=O)(=O)N2CCNCC2)c2occc12</smiles>

Scheme 4. Synthesis of benzofuran derivatives 11-14 (Visnaginone derivatives). 
band around $3200 \mathrm{~cm}^{-1}$ due to $\mathrm{OH}$ and $\mathrm{NH}$ functions and at $1668 \mathrm{~cm}^{-1}$ due to conjugated $\mathrm{C}=\mathrm{O}$ functional group. Mass spectrum showed a molecular ion peak at $\mathrm{m} / \mathrm{z}=409$, corresponding to a molecular formula $\mathrm{C}_{18} \mathrm{H}_{23} \mathrm{~N}_{3} \mathrm{O}_{6} \mathrm{~S}$. In addition, condensation of visnaginone $\mathbf{1 1}$ with 4-chlorobenzaldeyde gave the corresponding styryl derivative 13 which was condensed with phenylhydrazine to give the pyrazoline derivative $\mathbf{1 4}$ (Scheme 4). IR spectrum of compound $\mathbf{1 4}$ has no absorption band characteristic to $\mathrm{C}=\mathrm{O}$ group and it revealed the presence of $\mathrm{C}=\mathrm{N}$ band at $1597 \mathrm{~cm}^{-1} .{ }^{1} \mathrm{H} \mathrm{NMR}$ spectrum showed the presence of signals corresponding for piperazine and pyrazoline protons in addition to the presence of two broad signals at: 9.36 and 14.17 for $\mathrm{NH}$ and $\mathrm{OH}$, respectively.

In view of the growing biological importance of fuorocoumarin, particularly bergapten, it was of interest to synthesize some bergaptensulfonamides on the hope of obtaining more antimicrobial agents. Thus, cyclization of $\mathbf{1 1}$ with malononitrile or ethyl cyanoacetate in the presence of piperidine afforded furobenzopyransulfonamide derivatives 15a,b. Both elemental analysis and spectral data of the isolated products were in assignment with the proposed structure. IR spectra of $\mathbf{1 5 a , b}$ showed bands around $2200 \mathrm{~cm}^{-1}$ due to $\mathrm{C} \equiv \mathrm{N}$ functional group. Their ${ }^{1} \mathrm{H}$ NMR spectra exhibited two singlet signals around 2.42 and $4.10 \mathrm{ppm}$ specific for $\mathrm{CH}_{3}$ and $\mathrm{OCH}_{3}$ protons. Interaction of $\mathbf{1 5 b}$ with elemental sulfur in ethanolic morpholine yielded thiophene derivative 16 via thiation of methyl group followed by intermolecular cyclization (Scheme 5). Its IR spectrum showed the disappearance of $\mathrm{C} \equiv \mathrm{N}$ group and revealed bands at 3299 and $3414 \mathrm{~cm}^{-1}\left(\mathrm{NH}_{2}, \mathrm{NH}\right)$. In addition, interaction of compound $\mathbf{1 5 b}$ with 4-methoxybenzylidene malononitrile furnished benzopergapten derivative 17 . The formation of benzopergapten derivative $\mathbf{1 7}$ can be assumed via addition of methyl group in $\mathbf{1 5 b}$ to the activated double bond of arylidene to form intermediate. Cyclization of the latter intermediate formed another intermediate which subjected to elimination of HCN to form $\mathbf{1 7}$ (Scheme 5).

\section{Antibacterial and Antifungal Activities}

The synthesized compounds were tested in vitro for antibacterial and antifungal activities by the agar diffusion method against the following strains: two Gram-positive bacteria, Staphylococcus aureus NCTC-7447 and Bacillus cereus ATCC-14579; two Gram-negative bacteria, Pseudomonas oeruginosa IMRU-70, and Esherichia coli NCTC-289; and three Fungi, Aspergillus ochraceus Wilhelm AUCC-230, Penicillium chrysogenum thom AUCC-530 and Candida albicans AUCC-420. The results were summarized in Table 1. Most of the synthesized compounds exhibited various antimicrobial activity towards all the micro-organisms used.

Certain aspects of the structure activity relationships of the prepared compounds were clearly highlighted. The results of the antimicrobial screening demonstrated the following assumptions about the structural activity relationship (SAR). Incorporating piperazin-1-ylsulfonyl moiety in position 9 of visnagine as in structure $\mathbf{3}$ had a detrimental effect on antimicrobial activity. Visnagin-9-piperazin-1-ylsulfonyl $\mathbf{3}$

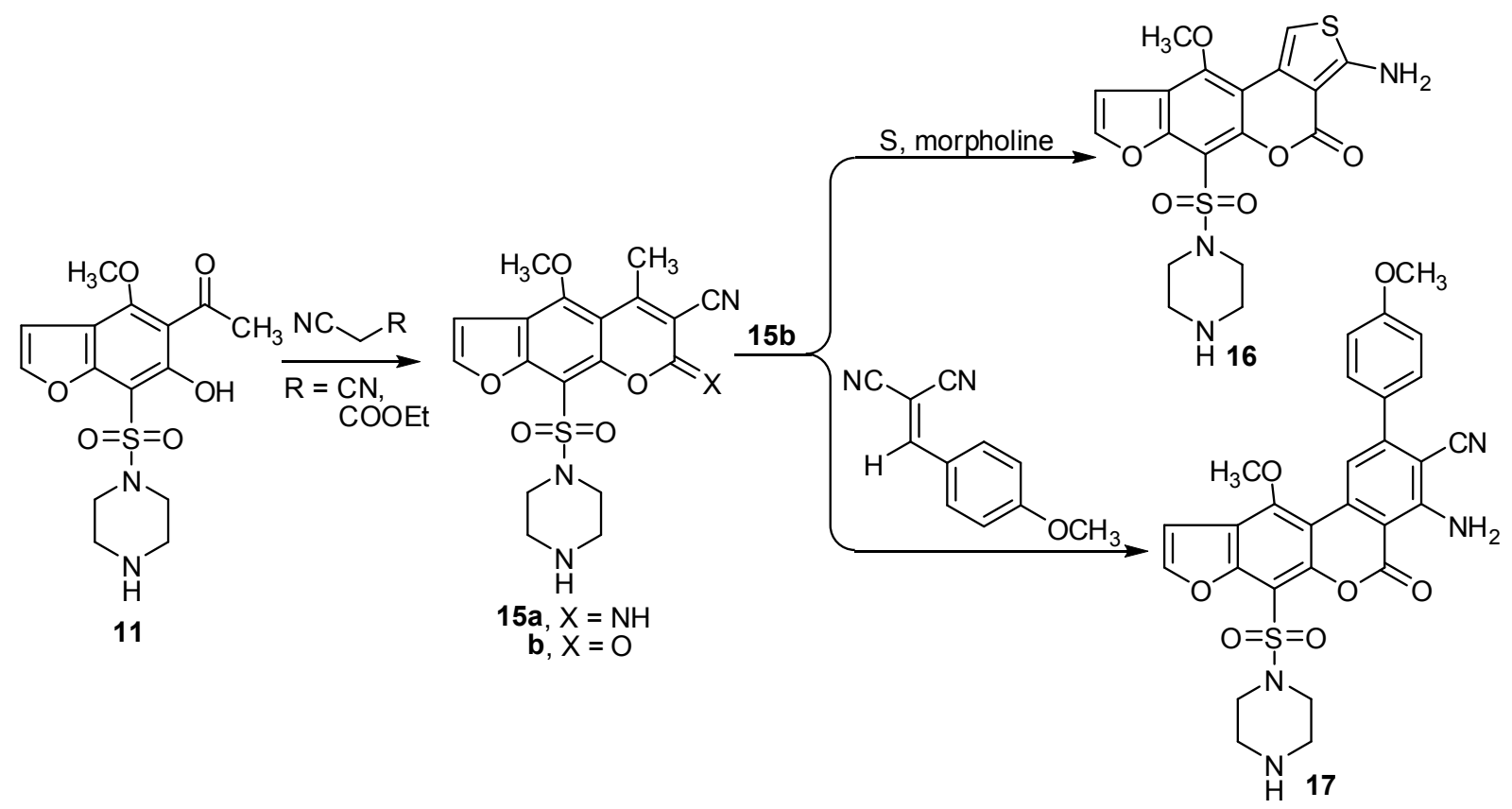

Scheme 5. Synthesis of furocoumarin derivatives 15a,b, 16 and 17 (furobenzopyransulfonamide [bergaptensulfonamides]). 
Table 1. Antimicrobial activity of the synthesized compounds against the pathological organisms expressed as inhibition diameter zones in millimeters $(\mathrm{mm})$ based on well diffusion assay

\begin{tabular}{cccccccc}
\hline \multirow{2}{*}{ Compd. No. } & \multicolumn{2}{c}{ Gram positive bacteria } & \multicolumn{2}{c}{ Gram negative bacteria } & \multicolumn{2}{c}{ Fungi } \\
& S. aureus & B. cereus & P. aeruginosae & E. coli & A. o. wilhelm & P. e. thom & C. albicans \\
\hline 3 & 5 & 10 & 6 & 12 & 13 & 5 & 0 \\
$4 a$ & 12 & 13 & 17 & 19 & 6 & 12 & 13 \\
$4 b$ & 13 & 15 & 16 & 18 & 14 & 14 & 6 \\
$4 c$ & 14 & 18 & 19 & 20 & 19 & 18 & 5 \\
5 & 19 & 0 & 9 & 5 & 5 & 5 & 8 \\
6 & 9 & 8 & 8 & 10 & 18 & 10 & 9 \\
8 & 10 & 6 & 11 & 18 & 0 & 0 & 0 \\
11 & 5 & 0 & 0 & 0 & 0 & 8 & 3 \\
12 & 9 & 5 & 0 & 5 & 0 & 0 & 0 \\
13 & 4 & 8 & 5 & 5 & 4 & 0 & 5 \\
14 & 0 & 4 & 0 & 5 & 4 & 0 & 17 \\
$15 a$ & 6 & 8 & 4 & 7 & 9 & 0 & 4 \\
$15 b$ & 5 & 9 & 5 & 8 & 8 & 0 & 5 \\
16 & 8 & 5 & 8 & 9 & 8 & 0 & 0 \\
17 & 8 & 7 & 7 & 8 & 7 & 0 & 0 \\
Chloramphenicol & 34 & 37 & 34 & 38 & ----- & -3 & 32 \\
Terbinafin & ----- & ----- & ----- & ----- & 35 & 37 \\
\hline
\end{tabular}

showed moderately active against all the tested strains. Changing the substituent on sulfonamide at position C-9 of visnagine from 2-ethoxyphenyl to 2-aminophenyl to 4aminobiphenyl (4a $\rightarrow \mathbf{4 b} \rightarrow \mathbf{4 c}$ ) to show the difference between each substituent on the effect of the antimicrobial activity was carried out. Compound $\mathbf{4 c}$ showed more activity than its analogues and showed high activities against all the tested strains. Incorporating sulfonamide-phenyl-acetamide moiety in position 9 of visnagine as in structure 5 did not improve the antimicrobial activity. Compound $\mathbf{5}$ showed moderately active against all the tested strains. Similarly, incorporating sulfonamide-biphenyl-4-yl-acetamide moiety in position 9 of visnagine as in structure 6 showed little improvement on antimicrobial activity. Compound $\mathbf{6}$ showed moderate activity against all the tested organisms. Surprising, incorporating $1 H$-benzo[d] [1,2,3]triazol1-ylsulfonyl moiety in position 9 of visnagine as in structure 8 did not showed remarkable improvement on the antimicrobial activity. Compound $\mathbf{8}$ showed moderately activity against all the tested bacteria and no activity against all the tested fungi. Broken $\gamma$-pyrone ring of visnagine as in structure $\mathbf{1 1}$ resulted in the lowest antimicrobial activity among all the investigated compounds. Visnaginone derivative $\mathbf{1 1}$ showed no activity against most of the tested bacteria and fungi. Treatment of 11 with dimethylformamide-dimethylacetal did not improve the antimicrobial activity. Compound $\mathbf{1 2}$ showed no activity against most of the tested bacteria and fungi. In addition, condensation of visnaginone $\mathbf{1 1}$ with 4-chlorobenzaldeyde did not improve the antimicrobial activity. Styryl derivative $\mathbf{1 3}$ showed no activity against most of the tested bacteria and fungi. Moreover, condensation of styryl derivative 13 with phenylhydrazine did not improve the antimicrobial activity. Pyrazole derivative $\mathbf{1 4}$ showed high activity against $C$. albicans only and no activity against most of the tested bacteria and fungi. Formation of fuorocoumarin (furobenzopyransulfonamide [bergaptensulfonamides]) 15a,b showed moderately active against all the tested strains. Treatment of $\mathbf{1 5 b}$ with sulfur or aryledine did not improve the antimicrobial activity.

\section{CONCLUSIONS}

Derivatives of furochromone, benzofuran and furocoumarin which bearing sulfonyl moiety were synthesized in order to evaluate their antibacterial and antifungal activities. Regarding the effect of each derivative against bacterial and fungal strains, results of antimicrobial activity in this study revealed that: Derivatives of visnagine with piperazin-1-ylsulfonyl moiety in position 9 showed moderate activity against all the tested strains. Changing the substituent at position C-9 of visnagine from $\mathrm{N}$-(2-ethoxyphenyl)-sulfonamide to $\mathrm{N}$-(2-aminophenyl)-sulfonamide or $\mathrm{N}$-(4-aminobiphenyl)-sulfonamide improved the antimicrobial activity. Besides, $\mathrm{N}$-(4-aminobiphenyl)-sulfonamide moiety showed higher activity against all the tested strains. Incorporating sulfonamide-phenyl-acetamide, sulfonamide-biphenyl4 -yl-acetamide or $1 \mathrm{H}$-benzo[d][1,2,3]triazol-1-ylsulfonyl moieties in position 9 of visnagine did not improve the antimicrobial activity. Broken $\gamma$-pyrone ring of visnagine 
resulted in the lowest antimicrobial activity among all the compounds investigated in this study. Formation of fuorocoumarin (furobenzopyran-sulfonamide [bergaptensulfonamides]) showed moderate activity against all the tested strains.

\section{EXPERIMENTAL}

Melting points were determined on a digital Gallen-Kamp MFB-595 instrument and were uncorrected. IR spectra $(\mathrm{KBr})$ were measured using a Jasco FT/IR-300E spectrometer. ${ }^{1} \mathrm{H}$ NMR were recorded on a Brucker $(500 \mathrm{MHz})$ spectrometer using TMS as an internal standard; chemical shifts are reported as $\delta / p p m$ units. Mass spectra were performed on a Shimadzu GSMS-QP 1000 Ex mass spectrometer at 70 $\mathrm{eV}$. The elemental analyses were carried out at the Microanalytical Center, Cairo University, Cairo, Egypt. Antimicrobial screening was carried out in Biochemistry Department Faculty of Agriculture, Al-Azhar University.

\section{General Procedure for the Synthesis of Visnagin-9-sulfonamide Derivatives 3 and $4 a-c$}

A mixture of 2 (0.01 mol), appropriate amines (namely; piperazine, $o$-phenatidine, $o$-phenylenediamines and 4,4'-diaminobiphenyl) $(0.01 \mathrm{~mol})$ and pyridine $(1 \mathrm{~mL})$ in dry benzene $(25 \mathrm{~mL})$ was heated under reflux for $2 \mathrm{~h}$, the solvent was evaporated and the resulting solids were crystallized from ethanol to give the corresponding compounds 3 and $4 a-c$.

\section{4-Methoxy-7-methyl-9-(piperazin-1-ylsulfonyl)-5H-} furo[3,2-g]chromen-5-one (3)

White crystals; m.p. > $300{ }^{\circ} \mathrm{C}$; IR $\tilde{v} / \mathrm{cm}^{-1}$ : 3245 (NH), 1665 $(\mathrm{C}=\mathrm{O}) ;{ }^{1} \mathrm{H}$ NMR (DMSO-d $\left.d_{6}\right) \delta / \mathrm{ppm}: 2.56\left(\mathrm{~s}, 3 \mathrm{H}, \mathrm{CH}_{3}\right.$ ), 2.74$3.56\left(\mathrm{~m}, 8 \mathrm{H}\right.$, piperazine moiety), $3.67\left(\mathrm{~s}, 3 \mathrm{H}, \mathrm{OCH}_{3}\right), 6.45(\mathrm{~s}$, $1 \mathrm{H}$, pyrone), $6.92-7.80(\mathrm{~m}, 2 \mathrm{H}$, furan- $\mathrm{H}), 9.88(\mathrm{br}, 1 \mathrm{H}, \mathrm{NH}$, $\mathrm{D}_{2} \mathrm{O}$-exchangeable); $\mathrm{MS}(\mathrm{m} / \mathrm{z}, \%): 378\left(\mathrm{M}^{+}, 54\right), 187$ (100); Anal. Calcd. for $\mathrm{C}_{17} \mathrm{H}_{18} \mathrm{~N}_{2} \mathrm{O}_{6} \mathrm{~S}$ (378.40): C, 53.96; $\mathrm{H}, 4.79 ; \mathrm{N}$, 7.40. Found: $\mathrm{C}, 54.11 ; \mathrm{H}, 4.64 ; \mathrm{N}, 7.56$.

\section{$\mathrm{N}$-(2-Ethoxyphenyl)-4-methoxy-7-methyl-5-oxo-5H- furo[3,2-g]chromene-9-sulfonamide (4a)} Yellow sheets; m.p. $192-194{ }^{\circ} \mathrm{C}$; IR $\tilde{v} / \mathrm{cm}^{-1}$ : 3239 (NH), 1661 $(\mathrm{C}=0) ;{ }^{1} \mathrm{H} \mathrm{NMR}\left(\mathrm{CDCl}_{3}\right): \delta / \mathrm{ppm}: 1.21\left(\mathrm{t}, 3 \mathrm{H}, J=6.85 \mathrm{~Hz}, \mathrm{CH}_{3}-\right.$ ethyl), $2.40\left(\mathrm{~s}, 3 \mathrm{H}, \mathrm{CH}_{3}\right), 3.89\left(\mathrm{~s}, 3 \mathrm{H}, \mathrm{OCH}_{3}\right), 4.22(\mathrm{q}, 2 \mathrm{H}, J=$ $6.85 \mathrm{~Hz}, \mathrm{CH}_{2}$-ethyl), 6.07 (s, 1H, $\mathrm{H}_{3}$-pyrone), 6.69-7.92 (m, 6H, $4 \mathrm{Ar}-\mathrm{H}+2$ furan- $\mathrm{H}), 8.61$ (br, $1 \mathrm{H}, \mathrm{NH} ; \mathrm{D}_{2} \mathrm{O}$-exchangeable); $\mathrm{MS}$ (m/z, \%): $429\left(\mathrm{M}^{+}, 38\right)$; Anal. Calcd. for $\mathrm{C}_{21} \mathrm{H}_{19} \mathrm{NO}_{7} \mathrm{~S}$ (429.45): C, 58.73; H, 4.46; N, 3.26. Found: C, 58.62; H, 4.51; N, 3.24.
$\mathrm{N}$-(2-Aminophenyl)-4-methoxy-7-methyl-5-oxo-5Hfuro[3,2-g]chromene-9-sulfonamide (4b) Yellow powder; m.p. $171-173{ }^{\circ} \mathrm{C}$; IR $\tilde{v} / \mathrm{cm}^{-1}$ : 3211, 3123 $\left(\mathrm{NH}, \mathrm{NH}_{2}\right), 1673(\mathrm{C}=\mathrm{O}) ;{ }^{1} \mathrm{H} \mathrm{NMR}\left(\mathrm{CDCl}_{3}\right): \delta / \mathrm{ppm}: 2.42(\mathrm{~s}, 3 \mathrm{H}$, $\left.\mathrm{CH}_{3}\right), 3.94\left(\mathrm{~s}, 3 \mathrm{H}, \mathrm{OCH}_{3}\right), 4.69\left(\mathrm{br}, 2 \mathrm{H}, \mathrm{NH}_{2}\right.$; cancelled with $\left.\mathrm{D}_{2} \mathrm{O}\right) ; 6.11\left(\mathrm{~s}, 1 \mathrm{H}, \mathrm{H}_{3}\right.$-pyrone), 6.55-7.72 (m, 6H, 4Ar-H + 2furan-H), 9.61 (s, $1 \mathrm{H}, \mathrm{NH} ; \mathrm{D}_{2} \mathrm{O}$-exchangeable); $\mathrm{MS}(\mathrm{m} / \mathrm{z}$, \%): $400\left(\mathrm{M}^{+}, 21\right), 229$ (17), 201 (33), 107 (100); Anal. Calcd. for $\mathrm{C}_{19} \mathrm{H}_{16} \mathrm{O}_{6} \mathrm{~N}_{2} \mathrm{O}_{6} \mathrm{~S}$ (400.41): C, 56.99; $\mathrm{H}, 4.03 ; \mathrm{N}, 7.00$. Found: $\mathrm{C}, 56.87 ; \mathrm{H}, 4.09 ; \mathrm{N}, 7.13$.

\section{$N$-(4'-Aminobiphenyl-4-yl)-4-methoxy-7-methyl-5-oxo- $\mathbf{5 H}$-furo[3,2-g]chromene-9-sulfonamide (4c)}

Pink crystals; m.p. $240-242{ }^{\circ} \mathrm{C}$; IR $\tilde{v} / \mathrm{cm}^{-1}$ : 3238, $3173(\mathrm{NH}$, $\mathrm{NH}_{2}$ ), 1663 (C=O); ${ }^{1} \mathrm{H}$ NMR (DMSO- $\left.d_{6}\right) \delta / p p m: 2.39$ (s, $3 \mathrm{H}$, $\left.\mathrm{CH}_{3}\right), 4.01\left(\mathrm{~s}, 3 \mathrm{H}, \mathrm{OCH}_{3}\right), 4.77\left(\mathrm{br}, 2 \mathrm{H}, \mathrm{NH}_{2} ; \mathrm{D}_{2} \mathrm{O}\right.$-exchangeable); 6.17 (s, $1 \mathrm{H}, \mathrm{H}_{3}$-pyrone), 6.55-7.70 (m, $10 \mathrm{H}, 8 \mathrm{Ar}-\mathrm{H}+$ 2furan-H), $9.61\left(\mathrm{~s}, 1 \mathrm{H}, \mathrm{NH} ; \mathrm{D}_{2} \mathrm{O}\right.$-exchangeable); $\mathrm{MS}(\mathrm{m} / \mathrm{z}$, \%): $476\left(\mathrm{M}^{+}, 34\right), 184$ (100); Anal. Calcd. for $\mathrm{C}_{25} \mathrm{H}_{20} \mathrm{~N}_{2} \mathrm{O}_{6} \mathrm{~S}$ (476.50): C, 63.02; H, 4.23; N, 5.88. Found: C, 63.14; H, 4.31; N, 5.68 .

\section{General Procedure for Acetylation of Compounds $4 \mathrm{~b}$ and $\mathbf{4 c}$}

The solution of $\mathbf{4 b}$ or $\mathbf{4 c}(0.01 \mathrm{~mol})$ in acetic anhydride (10 $\mathrm{mL}$ ) was heated under reflux for $2 \mathrm{~h}$. The reaction mixture was cooled and the solid product collected and crystallized from proper solvent to give $\mathbf{5}$ and $\mathbf{6}$, respectively.

N-(2-(4-Methoxy-7-methyl-5-oxo-5H-furo[3,2g]chromene-9-sulfonamido)phenyl)acetamide (5) Yellow powder, the solid was crystallized from toluene; m.p. $186-188^{\circ} \mathrm{C}$; IR $\tilde{v} / \mathrm{cm}^{-1}$ : 3271, 3160 (2NH), 1714, 1664 ( $2 \mathrm{C}=\mathrm{O}) ;{ }^{1} \mathrm{H}$ NMR (DMSO-d $\left.d_{6}\right) \delta / p p m: 2.22\left(\mathrm{~s}, 3 \mathrm{H}, \mathrm{CH}_{3}\right), 2.52$ (s, 3H, $\left.\mathrm{CH}_{3}\right), 4.18\left(\mathrm{~s}, 3 \mathrm{H}, \mathrm{OCH}_{3}\right), 6.09\left(\mathrm{~s}, 1 \mathrm{H}, \mathrm{H}_{3}-\right.$ pyrone), 6.96-7.43 (m, 7H, 4Ar-H + 2furan-H + NH), $9.45(\mathrm{br}, 1 \mathrm{H}, \mathrm{NH}$, $\mathrm{D}_{2} \mathrm{O}$-exchangeable); $\mathrm{MS}(\mathrm{m} / \mathrm{z}, \%): 442\left(\mathrm{M}^{+}, 43\right)$; Anal. Calcd. for $\mathrm{C}_{21} \mathrm{H}_{18} \mathrm{~N}_{2} \mathrm{O}_{7} \mathrm{~S}$ (442.44): $\mathrm{C}, 57.01 ; \mathrm{H}, 4.10 ; \mathrm{N}, 6.33$. Found: C, $57.10 ; \mathrm{H}, 4.20 ; \mathrm{N}, 6.40$.

$\mathrm{N}$-Acetyl-N-(4'-(4-methoxy-7-methyl-5-oxo-5H-furo[3,2g]chromene-9-sulfonamido) biphenyl-4-yl)acetamide (6) White crystals; the solid was crystallized from ethanol; m.p. $260-262{ }^{\circ} \mathrm{C}$; IR $\tilde{v} / \mathrm{cm}^{-1}$ : $3121(\mathrm{NH}), 1710,1662$ $(\mathrm{C}=\mathrm{O}) ;{ }^{1} \mathrm{H}$ NMR (DMSO- $\left.d_{6}\right) \delta / \mathrm{ppm}: 1.99\left(\mathrm{~s}, 3 \mathrm{H}, \mathrm{CH}_{3}\right), 2.32$ $\left(\mathrm{s}, 6 \mathrm{H}, 2 \mathrm{COCH}_{3}\right), 4.06\left(\mathrm{~s}, 3 \mathrm{H}, \mathrm{OCH}_{3}\right), 6.19\left(\mathrm{~s}, 1 \mathrm{H}, \mathrm{H}_{3}-\mathrm{py}-\right.$ rone), 7.25-8.24 (m, 11H, 8Ar-H + 2furan-H + NH); MS $(\mathrm{m} / \mathrm{z}, \%): 560\left(\mathrm{M}^{+}, 51\right)$; Anal. Calcd. for $\mathrm{C}_{29} \mathrm{H}_{24} \mathrm{~N}_{2} \mathrm{O}_{8} \mathrm{~S}$ (560.58): C, 62.13; H, 4.32; N, 5.00. Found: C, 62.20; H, $4.30 ; \mathrm{N}, 4.80$. 


\section{9-(1H-benzo[d][1,2,3]triazol-1-ylsulfonyl)-4-methoxy-7- methyl-5H-furo[3,2-g]chromen-5-one (8)}

A compound of $\mathbf{4 b}$ was dissolved in dil $\mathrm{HCl}(10 \mathrm{~mL})$ then cooled to $0{ }^{\circ} \mathrm{C}$ with stirring. A freshly solution of sodium nitrite $\left(0.01 \mathrm{~mol}\right.$ in $5 \mathrm{~mL} \mathrm{H}_{2} \mathrm{O}$ ) was gradually added. The solution was stirring for further $2 \mathrm{~h}$. , then the solid that formed was filtered off and crystallized from ethanol as white crystals; m.p. $150-151{ }^{\circ} \mathrm{C} ; \mathrm{IR} \tilde{\mathrm{v}} / \mathrm{cm}^{-1}$ : 1668 (C=O); ${ }^{1 \mathrm{H}} \mathrm{NMR}$ $\left(\mathrm{CDCl}_{3}\right): \delta / \mathrm{ppm}: 2.15\left(\mathrm{~s}, 3 \mathrm{H}, \mathrm{CH}_{3}\right), 3.87\left(\mathrm{~s}, 3 \mathrm{H}, \mathrm{OCH}_{3}\right), 6.01(\mathrm{~s}$, $1 \mathrm{H}, \mathrm{H}_{3}$-pyrone), 7.19-8.11 (m, 6H, 4Ar-H + 2furan-H); MS $(\mathrm{m} / \mathrm{z}, \%): 411\left(\mathrm{M}^{+}, 34\right)$; Anal. Calcd. for $\mathrm{C}_{19} \mathrm{H}_{13} \mathrm{~N}_{3} \mathrm{O}_{6} \mathrm{~S}$ (411.39): C, 55.47; H, 3.19; N, 10.21. Found: C, 55.60; H, 3.32; N, 10.43.

\section{4-Methoxy-5-(5-methyl-1H-pyrazol-3-yl)-7-(piperazin-1- ylsulfonyl)-benzofuran-6-ol (9)}

A mixture of $3(0.01 \mathrm{~mol})$ and hydrazine hydrate $(0.012 \mathrm{~mol})$ in ethanol $(30 \mathrm{~mL})$ was heated under reflux for $3 \mathrm{~h}$, the reaction mixture was cooled and the solid was collected and recrystallized from ethanol as yellow powder; m.p. 208$210{ }^{\circ} \mathrm{C}$; IR $\tilde{v} / \mathrm{cm}^{-1}$ : 3392 (br, OH/ 2NH), 2949 (CH-aliph.), $1598(\mathrm{C}=\mathrm{N}) ;{ }^{1} \mathrm{H}$ NMR (DMSO- $\left.d_{6}\right) \delta / \mathrm{ppm}: 2.56\left(\mathrm{~s}, 3 \mathrm{H}, \mathrm{CH}_{3}\right)$, 2.74-3.56 (m, 8H, piperazine moiety), $3.67\left(\mathrm{~s}, 3 \mathrm{H}, \mathrm{OCH}_{3}\right)$, $6.45(\mathrm{~s}, 1 \mathrm{H}$, pyrazole), 6.92-7.80 (m, 3H, 2furan- $\mathrm{H}+\mathrm{NH})$, 10.41 (br, $1 \mathrm{H}, \mathrm{NH}, \mathrm{D}_{2} \mathrm{O}$-exchangeable), 11.14 (br, $1 \mathrm{H}, \mathrm{OH}$; $\mathrm{D}_{2} \mathrm{O}$-exchangeable); $\mathrm{MS}(\mathrm{m} / \mathrm{z}, \%): 392\left(\mathrm{M}^{+}, 61\right)$; Anal. Calcd. for $\mathrm{C}_{17} \mathrm{H}_{20} \mathrm{~N}_{4} \mathrm{O}_{5} \mathrm{~S}$ (392.43): C, 52.03; $\mathrm{H}, 5.14 ; \mathrm{N}, 14.28$. Found: C, 52.22; H, 5.33; N, 14.10 .

\section{4-(6-Hydroxy-4-methoxy-7-(piperazin-1-ylsulfonyl)ben- zofuran-5-yl)-6-methylpyrimidine-2(1H)-thione (10)}

A mixture of $3(0.01 \mathrm{~mol})$, thiourea $(0.012 \mathrm{~mol})$ and potassium carbonate $(0.5 \mathrm{~g})$ in ethanol $(30 \mathrm{~mL})$ was heated under reflux for $3 \mathrm{~h}$, the reaction mixture was cooled then acidified with dil. $\mathrm{HCl}$. The solid product was collected and recrystallized from ethanol to give $\mathbf{1 0}$ as yellow powder; m.p. 138$140{ }^{\circ} \mathrm{C}$; IR $\tilde{v} / \mathrm{cm}^{-1}$ : 3443, 3221 (br, OH/ 2NH), 2925 (CH-aliph.), 1593 (C=N), 1280 (C=S); ${ }^{1} \mathrm{H}$ NMR (DMSO-d $\left.d_{6}\right) \delta / p p m$ : $2.51\left(\mathrm{~s}, 3 \mathrm{H}, \mathrm{CH}_{3}\right)$ 2.56-3.16 (m, 8H, piperazine), $3.41(\mathrm{~s}, 3 \mathrm{H}$, $\left.\mathrm{OCH}_{3}\right), 7.34$ (s, $1 \mathrm{H}$, pyrimidine), $7.41\left(\mathrm{~d}, 1 \mathrm{H}, J=2 \mathrm{~Hz}, \mathrm{H}_{3}\right.$-furan), $7.97\left(\mathrm{br}, 1 \mathrm{H}, \mathrm{NH}, \mathrm{D}_{2} \mathrm{O}\right.$-exchangeable), $8.06(\mathrm{~d}, 1 \mathrm{H}, J=$ $2.2 \mathrm{~Hz}, \mathrm{H}_{2}$-furan), 9.59 (br, $1 \mathrm{H}, \mathrm{NH}, \mathrm{D}_{2} \mathrm{O}$-exchangeable), 13.05 (br, $1 \mathrm{H}, \mathrm{OH}, \mathrm{D}_{2} \mathrm{O}$-exchangeable); $\mathrm{MS}(\mathrm{m} / \mathrm{z}, \%): 436$ $\left(\mathrm{M}^{+}, 26\right)$; Anal. Calcd. for $\mathrm{C}_{18} \mathrm{H}_{20} \mathrm{~N}_{4} \mathrm{O}_{5} \mathrm{~S}_{2}$ (436.51): C, 49.53; $\mathrm{H}$, 4.62; N, 12.84. Found: C, 49.58; H, 4.60; N, 12.93.

\section{1-(6-Hydroxy-4-methoxy-7-(piperazin-1-ylsulfonyl)benzo- furan-5-yl)ethanone (11)}

A mixture of compound $\mathbf{3}(0.01 \mathrm{~mol})$ and potassium hydroxide $(20 \%, 30 \mathrm{~mL})$ was heated under reflux for about $4 \mathrm{~h}$., then cooled and poured into ice/ $\mathrm{HCl}$. The obtained product was filtered off, washed several time with water and crystallized from ethanol as white powder; m.p. > $300{ }^{\circ} \mathrm{C}$; IR $\tilde{v} / \mathrm{cm}^{-1}: 3165(\mathrm{OH}), 3124(\mathrm{NH}), 2922,2841$ (CH-aliph.), 1666 $(\mathrm{C}=\mathrm{O}) ;{ }^{1} \mathrm{H}$ NMR (DMSO- $\left.d_{6}\right) \delta / \mathrm{ppm}: 2.58\left(\mathrm{~s}, 3 \mathrm{H}, \mathrm{COCH}_{3}\right)$, 2.68-3.33 (m, 8H, piperazine), $4.29\left(\mathrm{~s}, 3 \mathrm{H}, \mathrm{OCH}_{3}\right), 7.50(\mathrm{~d}$, $1 \mathrm{H}, J=2.02 \mathrm{~Hz}, \mathrm{H}_{3}$-furan) 7.81 (d, $1 \mathrm{H}, J=2.01 \mathrm{~Hz}, \mathrm{H}_{2}$-furan), 10.26 (br, $1 \mathrm{H}, \mathrm{NH}, \mathrm{D}_{2} \mathrm{O}$-exchangeable), $13.13(\mathrm{br}, 1 \mathrm{H}, \mathrm{OH}$, $\mathrm{D}_{2} \mathrm{O}$-exchangeable); $\mathrm{MS}(\mathrm{m} / \mathrm{z}, \%): 354\left(\mathrm{M}^{+}, 41\right)$; Anal. Calcd. for $\mathrm{C}_{15} \mathrm{H}_{18} \mathrm{~N}_{2} \mathrm{O}_{6} \mathrm{~S}$ (354.38): C, 50.84; $\mathrm{H}, 5.12 ; \mathrm{N}, 7.90$. Found: C, 50.94; H, 5.21; N, 7.84 .

3-(Dimethylamino)-1-(6-hydroxy-4-methoxy-7-(piperazin-

1-ylsulfonyl)benzofuran-5-yl)prop-2-en-1-one (12)

A mixture of compound $\mathbf{1 1}(0.01 \mathrm{~mol})$ and dimethylformamide dimethylacetal $(0.015 \mathrm{~mol})$ in xylene $(15 \mathrm{~mL})$ was heated under reflux for $3 \mathrm{~h}$., the obtained product was filtered off, washed with petroleum ether and crystallized from ethanol as yellow crystals; m.p. $149-150{ }^{\circ} \mathrm{C} ; \mathrm{IR} \tilde{\mathrm{v}} / \mathrm{cm}^{-1}$ : 3200 (br, NH/OH), 2926, 2846 (CH-aliph.), 1664 (C=O); ${ }^{1} \mathrm{H}$

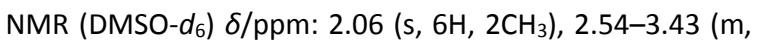
$8 \mathrm{H}$, piperazine), $3.99\left(\mathrm{~s}, 3 \mathrm{H}, \mathrm{OCH}_{3}\right), 6.78-7.81(\mathrm{~m}, 4 \mathrm{H}$, $\mathrm{CH}=\mathrm{CH}+$ furan- $\mathrm{H}), 10.26\left(\mathrm{br}, 1 \mathrm{H}, \mathrm{NH}, \mathrm{D}_{2} \mathrm{O}\right.$-exchangeable), $13.13\left(\mathrm{br}, 1 \mathrm{H}, \mathrm{OH}\right.$, exchangeable with $\left.\mathrm{D}_{2} \mathrm{O}\right)$; $\mathrm{MS}(\mathrm{m} / \mathrm{z}, \%)$ : $409\left(\mathrm{M}^{+}, 17.3\right), 51$ (100); Anal. Calcd. for $\mathrm{C}_{18} \mathrm{H}_{23} \mathrm{~N}_{3} \mathrm{O}_{6} \mathrm{~S}$ (409.46) C, 52.80; H, 5.66; N, 10.26. Found: C, 52.71; H, $5.73 ; \mathrm{N}, 10.46$.

3-(4-Chlorophenyl)-1-(6-hydroxy-4-methoxy-7-(piperazin1-ylsulfonyl)benzofuran-5-yl)prop-2-en-1-one (13) A mixture of 11 (0.01 mol), 4-chlorobenzaldehyde and piperidine $(0.5 \mathrm{~mL})$ in ethanol $(30 \mathrm{~mL})$ was heated under reflux for $4 \mathrm{~h}$. The solid obtained was collected and recrystallized from ethanol as a yellow powder; m.p. 178$180^{\circ} \mathrm{C} ; \mathrm{IR} \tilde{\mathrm{v}} / \mathrm{cm}^{-1}$ : 3159 (br, NH/OH); 2954, 2823 (CH-aliph.), 1660 (C=O); ${ }^{1} \mathrm{H}$ NMR ( $\left.\mathrm{CDCl}_{3}\right): \delta / p p m: 2.66-3.18(\mathrm{~m}, 8 \mathrm{H}$, piperazine), $3.91\left(\mathrm{~s}, 3 \mathrm{H}, \mathrm{OCH}_{3}\right), 6.80-7.85(\mathrm{~m}, 8 \mathrm{H}, \mathrm{CH}=\mathrm{CH}+$ $4 \mathrm{Ar}-\mathrm{H}+2$ furan- $\mathrm{H}), 10.61\left(\mathrm{br}, 1 \mathrm{H}, \mathrm{NH}, \mathrm{D}_{2} \mathrm{O}\right.$-exchangeable), $13.60\left(\mathrm{br}, 1 \mathrm{H}, \mathrm{OH}, \mathrm{D}_{2} \mathrm{O}\right.$-exchangeable); $\mathrm{MS}(\mathrm{m} / \mathrm{z}, \%): 477$ $\left(\mathrm{M}^{+}, 72\right)$; Anal. Calcd. for $\mathrm{C}_{22} \mathrm{H}_{21} \mathrm{ClN}_{2} \mathrm{O}_{6} \mathrm{~S}$ (476.93): C, 55.40; $H, 4.44 ; N, 5.87$. Found: $C, 55.52 ; H, 4.33 ; N, 5.96$.

\section{5-(5-(4-Chlorophenyl)-1-phenyl-4,5-dihydro-1H-pyrazol-3-} yl)-4-methoxy-7-(piperazin-1-ylsulfonyl)benzofuran-6-ol (14) A mixture of $13(0.01 \mathrm{~mol})$ and phenylhydrazine $(0.01 \mathrm{~mL})$ in ethanol $(30 \mathrm{~mL})$ was heated under reflux for $3 \mathrm{~h}$. The reaction mixture was cooled, the solid product was filtered off and crystallized from ethanol as a brown powder; m.p. $133-135{ }^{\circ} \mathrm{C}$; IR $\tilde{v} / \mathrm{cm}^{-1}$ : 3255 (br, NH/OH), 2924, 2854 (CH-aliph.); ${ }^{1} \mathrm{H}$ NMR (DMSO- $d_{6}$ ) $\delta / p p m: ~ 2.73-$ $3.58(\mathrm{~m}, 10 \mathrm{H}, 8$ piperazine- $\mathrm{H}+2$ pyrazoline- $\mathrm{H}), 4.00(\mathrm{~s}, 3 \mathrm{H}$, $\left.\mathrm{OCH}_{3}\right), 4.80(\mathrm{~d}, 1 \mathrm{H}$, pyrazoline-H), 6.77-8.55 (m, 11H, 9Ar$\mathrm{H}+2$ furan- $\mathrm{H}), 9.36$ (br, $1 \mathrm{H}, \mathrm{NH}, \mathrm{D}_{2} \mathrm{O}$-exchangeable), 14.17 (br, $\mathrm{H}, \mathrm{OH}, \mathrm{D}_{2} \mathrm{O}$-exchangeable); $\mathrm{MS}(\mathrm{m} / \mathrm{z}, \%)$ : $567\left(\mathrm{M}^{+}, 29\right)$; Anal. Calcd. for $\mathrm{C}_{28} \mathrm{H}_{27} \mathrm{ClN}_{4} \mathrm{O}_{5} \mathrm{~S}$ (567.06) C, 59.31; $\mathrm{H}, 4.80$; N, 9.88. Found: C, 59.54; H, 4.67; N, 9.93. 


\section{General Procedure for the Synthesis of 7-substitued furo[3,2-g] Chromen-6-car- bonitrile Derivatives 15a,b}

A mixture of 14 (0.01 mol), malnonitrtile or ethyl cyanoacetate $(0.01 \mathrm{~mol})$ and piperidine $(0.5 \mathrm{~mL})$ in ethanol $(20 \mathrm{~mL})$ was heated under reflux for $3 \mathrm{~h}$. The solid product was collected and recrystallized from ethanol to give the corresponding compounds $15 \mathbf{a}, \mathbf{b}$.

\section{7-Imino-4-methoxy-5-methyl-9-(piperazin-1-ylsulfonyl)-} 7H-furo[3,2-g]chromene-6-carbonitrile (15a)

Brown crystals; m.p. $>300^{\circ} \mathrm{C}$; IR $\tilde{v} / \mathrm{cm}^{-1}: 3341,3302(2 \mathrm{NH})$, 2925 (CH-aliph.), 2196 (C $\equiv \mathrm{N}) ;{ }^{1} \mathrm{H}$ NMR (DMSO-d $\left.d_{6}\right) \delta / \mathrm{ppm}$ : $2.44\left(\mathrm{~s}, 3 \mathrm{H}, \mathrm{CH}_{3}\right), 2.78-3.54(\mathrm{~m}, 8 \mathrm{H}$, piperazine), $4.08(\mathrm{~s}, 3 \mathrm{H}$, $\left.\mathrm{OCH}_{3}\right), 6.77\left(\mathrm{~d}, 1 \mathrm{H}, J=2.0 \mathrm{~Hz}\right.$, furan- $\left.\mathrm{H}_{3}\right), 7.36(\mathrm{br}, 1 \mathrm{H}, \mathrm{NH}$, $\mathrm{D}_{2} \mathrm{O}$-exchangeable), $7.94\left(\mathrm{~d}, 1 \mathrm{H}, \mathrm{J}=2.1 \mathrm{~Hz}\right.$, furan- $\left.\mathrm{H}_{2}\right), 10.43$ (br, $1 \mathrm{H}, \mathrm{NH}, \mathrm{D}_{2} \mathrm{O}$-exchangeable); $\mathrm{MS}(\mathrm{m} / \mathrm{z}, \%): 402\left(\mathrm{M}^{+}, 76\right)$; Anal. Calcd. for $\mathrm{C}_{18} \mathrm{H}_{18} \mathrm{~N}_{4} \mathrm{O}_{5} \mathrm{~S}(402.42) \mathrm{C}, 53.72 ; \mathrm{H}, 4.51 ; \mathrm{N}$, 13.92. Found: $\mathrm{C}, 53.62 ; \mathrm{H}, 4.56 ; \mathrm{N}, 13.98$.

4-Methoxy-5-methyl-7-oxo-9-(piperazin-1-ylsulfonyl)-7Hfuro[3,2-g]chromene-6-carbonitrile (15b)

Brown needles; m.p. > $300{ }^{\circ} \mathrm{C}$; IR $\tilde{v} / \mathrm{cm}^{-1}$ : 3204 (NH), 2926 (CH-aliph.), $2221(\mathrm{C} \equiv \mathrm{N}), 1705$ ( $\mathrm{C}=\mathrm{O}$ of $\alpha$-pyrone); ${ }^{1} \mathrm{H}$ NMR (DMSO-d $\left.d_{6}\right) \delta / p p m: ~ 2.42\left(\mathrm{~s}, 3 \mathrm{H}, \mathrm{CH}_{3}\right), 3.30-3.51(\mathrm{~m}, 8 \mathrm{H}, \mathrm{pi}-$ perazine), $3.94\left(\mathrm{~s}, 3 \mathrm{H}, \mathrm{OCH}_{3}\right), 6.75(\mathrm{~d}, 1 \mathrm{H}, J=2.2 \mathrm{~Hz}$, furan$\left.\mathrm{H}_{3}\right), 7.32\left(\mathrm{br}, 1 \mathrm{H}, \mathrm{NH}, \mathrm{D}_{2} \mathrm{O}\right.$-exchangeable), $7.94(\mathrm{~d}, 1 \mathrm{H}, J=$ $2.1 \mathrm{~Hz}$, furan- $\left.\mathrm{H}_{2}\right)$; $\mathrm{MS}(\mathrm{m} / \mathrm{z}, \%): 403\left(\mathrm{M}^{+}, 28\right)$; Anal. Calcd. for $\mathrm{C}_{18} \mathrm{H}_{17} \mathrm{~N}_{3} \mathrm{O}_{6} \mathrm{~S}$ (403.41) C, 53.59; $\mathrm{H}, 4.25 ; \mathrm{N}, 10.42$. Found: $\mathrm{C}$, 53.73; H, 4.32; N, 10.64 .

Synthesis of 3-amino-10-methoxy-6-(piperazin-1-ylsulfonyl)-4H-furo[3,2-g]thieno[3,4-c]chromen-4-one (16) A mixture of $15 b(0.01 \mathrm{~mol})$ and sulfur $(0.01 \mathrm{~mol})$ in ethanol $(30 \mathrm{~mL})$ containing triethylamine $(0.5 \mathrm{~mL})$ was heated under reflux for $3 \mathrm{~h}$, the obtained solid was collected and crystallized from ethanol as brown crystals; m.p. $119-120^{\circ} \mathrm{C}$; IR $\tilde{v} / \mathrm{cm}^{-1}$ : 3414, 3299 (NH/NH 2$), 2987,2927$ (CH-aliph.), 1702 ( $\mathrm{C}=\mathrm{O}$ of $\alpha$-pyrone); ${ }^{1} \mathrm{H}$ NMR (DMSO- $d_{6}$ ) $\delta /$ ppm: $2.76-3.51$ ( $\mathrm{m}, 8 \mathrm{H}$, piperazine), $3.86\left(\mathrm{~s}, 3 \mathrm{H}, \mathrm{OCH}_{3}\right), 6.75-7.94(\mathrm{~m}, 5 \mathrm{H}, 2$ furan- $\mathrm{H}+$ thiophen- $\left.\mathrm{H}+\mathrm{NH}_{2}\right), 9.32\left(\mathrm{br}, 1 \mathrm{H}, \mathrm{NH}, \mathrm{D}_{2} \mathrm{O}\right.$-exchangeable); MS $(m / z, \%): 435\left(\mathrm{M}^{+}, 44\right)$; Anal. Calcd. for $\mathrm{C}_{18} \mathrm{H}_{17} \mathrm{~N}_{3} \mathrm{O}_{6} \mathrm{~S}_{2}$ (435.47) C, 49.65; $\mathrm{H}, 3.93 ; \mathrm{N}, 9.65$. Found: $\mathrm{C}$, 49.83; H, 3.81; N, 9.76 .

\section{Synthesis of 4-amino-11-methoxy-2-(4-methoxyphenyl)- 5-oxo-7-(piperazin-1-ylsulf-onyl)-5H-benzo[c]furo[3,2- g]chromene-3-carbonitrile (17)}

A mixture of 15b (0.01 mol), 4-methoxybenzylidene-malononitrile $(0.01 \mathrm{~mol})$ and piperidine $(1 \mathrm{~mL})$ in dimethyl formamide $(20 \mathrm{~mL})$ was heated under reflux for $4 \mathrm{~h}$. The product was filtered off and crystallized from ethanol as yellow crystals; m.p. $149-150{ }^{\circ} \mathrm{C}$; IR $\tilde{v} / \mathrm{cm}^{-1}$ : 3360, 3139
(NH/NH $\left.\mathrm{NH}_{2}\right), 2928$ (CH-aliph.), $2208(\mathrm{C} \equiv \mathrm{N}), 1707(\mathrm{C}=\mathrm{O}) ;{ }^{1} \mathrm{H}$ NMR (DMSO- $\left.d_{6}\right) \delta / p p m: 2.86-3.48(\mathrm{~m}, 8 \mathrm{H}$, piperazine), $3.56\left(\mathrm{~s}, 3 \mathrm{H}, \mathrm{OCH}_{3}\right), 3.78\left(\mathrm{~s}, 3 \mathrm{H}, \mathrm{OCH}_{3}\right), 7.31-7.88(\mathrm{~m}, 9 \mathrm{H}, 5$ Ar- $\mathrm{H}+2$ furan- $\left.\mathrm{H}+\mathrm{NH}_{2}\right), 9.13\left(\mathrm{br}, 1 \mathrm{H}, \mathrm{NH}, \mathrm{D}_{2} \mathrm{O}\right.$-exchangeable); $\mathrm{MS}(\mathrm{m} / \mathrm{z}, \%): 560\left(\mathrm{M}^{+}, 54\right)$; Anal. Calcd. for $\mathrm{C}_{28} \mathrm{H}_{24} \mathrm{~N}_{4} \mathrm{O}_{7} \mathrm{~S}$ (560.58) C, 59.99; H, 4.32; N, 9.99. Found: C, 59.73; H, 4.30; N, 9.80 .

\section{Antimicrobial Assay}

The synthesized compounds were screened in vitro for their antimicrobial activities against strains of bacteria and strains of fungi by the agar diffusion technique. ${ }^{[1]}$ A 1 $\mathrm{mg} / \mathrm{mL}$ solution in dimethylformamide was used. The bacteria and fungi were maintained on nutrient agar and Czapek's-Dox agar media, respectively. DMF showed no inhibition zones. The agar media were inoculated with different microorganisms culture tested. After $24 \mathrm{~h}$ of incubation at $37^{\circ} \mathrm{C}$ for bacteria and $48 \mathrm{~h}$ of incubation at $28^{\circ} \mathrm{C}$ for fungi, the diameter of inhibition zone $(\mathrm{mm})$ was measured. Chloramphenicol and Terbinafin used as references for antibacterial and antifungal activities, respectively.

\section{REFERENCES}

[1] S.Y. Abbas, M.A.M. Sh. El-Sharief, W. M. Basyouni, I. M. I. Fakhr, E. W. El-Gammal, Eur. J. Med. Chem. 2013, 64, 111.

[2] M. H. Helal, S. Y. Abbas, M. A. Salem, A. A. Farag, Y. A. Ammar, Med. Chem. Res. 2013, 22, 5598.

[3] M. A. M. Sh. El-Sharief, S. Y. Abbas, K. A. M. ElBayouki, E. W. El-Gammal, Eur. J. Med. Chem. 2013, 67, 263.

[4] K. Asoh, M. Kohchi, I. Hyoudoh, T. Otsuka, M. Masubuchi, K. Kawasaki, H. Ebiike, Y. Shiratori, T. A. Fukami, O. Kondoh, T. Tsukaguchi, N. Ishii, Y. Aoki, N. Shimma, M. Sakaitani, Bioorg. Med. Chem. Lett. 2009, 19, 1753.

[5] S. K. Lee, B. Cui, R. R. Mehta, A. D. Kinghorn, J. M. Pezutto, Chem. Biol. Interact. 1998, 115, 215.

[6] M. Koca, S. Servi, C. Kirilmis, M. Ahmedzade, C. Kazas, Eur. J. Med. Chem. 2005, 40, 1351.

[7] J. Nawrot-Modranka, E. Nawrot, J. Graczyk, Eur. J. Med. Chem. 2006, 41, 1301.

[8] B-d. Wang, Z-Y. Yang, T-r. Li, Bioorg. Med. Chem. 2006, 14, 6012.

[9] L. Pisco, M. Kordian, K. Peseke, H. Feist, D. Michalik, E. Estrada, J. Carvalho, G. Hamilton, D. Rando, J. Quincoces, Eur. J. Med. Chem. 2006, 41, 401.

[10] M. Ghate, R. A. Kusanur, M. V. Kulkarni, Eur. J. Med. Chem. 2005, 40, 882.

[11] B. H. Havsteen, Pharmacol Ther. 2002, 96, 67.

[12] A. K. Gadad, C. S. Mahajanshetti, S. Nimbalkar, A. Raichurkar, Eur. J. Med. Chem. 2000, 35, 853. 
[13] T. Narasaiaha, D. Subba Raoa, K. Venkata Ramanaa, S. Adamb, C. Naga Raju, Der Pharma Chemica, 2012, 4, 1582.

[14] I. Argyropoulou, A. Geronikaki, P. Vicini, F. Zani, ARKIVOC 2009, (vi), 89.

[15] Z. Franca, V. Paola, Archiv der Pharmazie. 1998, 331, 219.

[16] S. Alyar, N. Karacan, J. Enzyme Inhib. Med. Chem. 2009, 24, 986.

[17] A. A. Farag, S. N. Abd-Alrahman, G. F. Ahmed, R. M. Ammar, Y. A. Ammar, S. Y. Abbas, Arch. Pharm. Life Sci. 2012, 345, 703.

[18] A. A. Farag, Y. A. Ammar, A.-A. G. El-Sehemi, H. Kh. Thabet, N. A. Hassan, A. Kh. Samy, J. Chem. Res. 2011, 163, 163.

[19] Y. A. Ammar, M. M. Aly, A.-A. G. Al-Sehemi, M. A. Salem, M. S. A. El-Gaby, J. Chinese chem. Soc. 2009, 183, 1064.
[20] M. M. Ghorab, E. Noaman, M. M. F. Ismail, H. I. Heiba, Y. A. Ammar, M. Y. Sayed, Arzneim-Forsch /Drug Research 2006, 56, 405.

[21] S. Y. Abbas, A. A. Farag, Y. A. Ammar, A. A. Atrees, A. F. Mohamed, A. A. El-Henawy, Monatsh Chem. 2013, 144, 1725.

[22] Y. A. Ammar, H. M. El-Sehrawi, H. S. A. El-Zahabi, T. Z. Shawer, M. M. F. Ismail, Der Pharma Chemica 2012, 4, 2140.

[23] Y. A. Ammar, H. Kh. Thabet, M. M. Aly, Y. A. Mohamed, M. A. Ismail, M. A. Salem, Phosphorus sulfur and silicon 2010, 185, 743.

[24] M. H. Helal, G. A. M. El-Hag Ali, A. A. Ali, Y. A. Ammar, J. Chem. Res. 2010, 465, 465.

[25] G. A. M. El-Hag Ali, M. H. Helal, Y. A. Mohamed, A. A. Ali, Y. A. Ammar, J. Chem. Res. 2010, 469, 459.

[26] M. H. A. Elgamal, N. M. M. Shalaby, H. Duddeck, D. Rasenbaum, J. Heterocyclic Chem. 1987, 24, 721. 